\title{
Solimonas soli gen. nov., sp. nov., isolated from soil of a ginseng field
}

\author{
Myung Kyum Kim, ${ }^{1}$ Yu-Jin Kim, ${ }^{1}$ Dong-Ha Cho, ${ }^{2}$ Tae-Hoo Yi, ${ }^{1}$ \\ Nak-Kyun Soung ${ }^{3}$ and Deok-Chun Yang ${ }^{1}$
}

Correspondence

Deok-Chun Yang

deokchunyang@yahoo.co.kr

\author{
${ }^{1}$ Department of Oriental Medicinal Material and Processing, College of Life Science, Kyung Hee \\ University, 1 Seocheon-dong, Giheung-gu Yongin, Kyunggi-do 449-701, South Korea \\ ${ }^{2}$ Kanwon National University, School of Bioscience and Biotechnology, Chunchon 200-701, \\ South Korea \\ ${ }^{3}$ Laboratory of Metabolism, Center for Cancer Research, National Cancer Institute, NIH, \\ Bethesda, MD 20892, USA
}

\begin{abstract}
A micro-organism, DCY $12^{\top}$, comprising Gram-negative, non-motile, pale-yellow rods was isolated from soil from a ginseng field in South Korea and was investigated to determine its taxonomic status. It grew optimally at $30{ }^{\circ} \mathrm{C}$ and at $\mathrm{pH} 7.0$, the $\mathrm{G}+\mathrm{C}$ content of its DNA was $40.5 \mathrm{~mol} \%$, the major components of the fatty acid profile were $\mathrm{C}_{16: 0}$ and $\mathrm{C}_{18: 1}$ and the major ubiquinone was Q-8. A phylogenetic analysis based on the 16S rRNA gene sequence revealed that the novel isolate was most closely related to Hydrocarboniphaga effusa AP103 ${ }^{\top}(89.2 \%)$, Nevskia ramosa Soe1 (88.8\%) and Pseudomonas aeruginosa ATCC $10145^{\top}(83.2 \%)$. The phenotypic, physiological, metabolic and phylogenetic properties of DCY $12^{\top}$ suggest that it represents a novel genus (class Gammaproteobacteria) and species, for which the name Solimonas soli gen. nov., sp. nov. is proposed. The type strain of Solimonas soli is DCY $12^{\top}$ $\left(=\right.$ KCTC $12834^{\top}=$ LMG $\left.24014^{\top}\right)$.
\end{abstract}

In a series of studies, we attempted to isolate microorganisms from soil in order to investigate the community structure by using a culture-dependent method. In the course of this study, strain DCY $12^{\mathrm{T}}$ was isolated from soil from a ginseng field near Daejeon in South Korea and was characterized by using a polyphasic approach. The polyphasic approach, which included a phylogenetic analysis based on 16S rRNA gene sequences, genomic relatedness studies and the determination of various chemotaxonomic and phenotypic properties, was designed to elucidate the precise taxonomic position of this strain. The results obtained in this study indicated that DCY $12^{\mathrm{T}}$ represents a novel species of a novel genus within the Gammaproteobacteria.

Strain DCY $12^{\mathrm{T}}$ was isolated from surface soil from an agricultural field in which ginseng was growing. A soil sample (1 g) was immersed in $50 \mathrm{ml}$ saline solution, vortexed and serially diluted and then an aliquot $(100 \mu \mathrm{l})$ was inoculated onto 10-fold-diluted R2A agar (Difco). Single colonies on these agar plates were purified by

\footnotetext{
The GenBank/EMBL/DDBJ accession number for the 16S rRNA gene sequence of strain DCY $12^{\top}$ is EF067861.

The cellular fatty acid profile of strain DCY $12^{\top}$ is available as supplementary material with the online version of this paper.
}

transferring them onto new plates and subjecting them to additional incubation for 5 days at $30{ }^{\circ} \mathrm{C}$. The purified colonies were tentatively identified using a partial sequence of the $16 \mathrm{~S}$ rRNA gene.

Cell morphology and motility were observed with a Nikon light microscope ( $\times 1000$ magnification), using cells grown on R2A agar at $30{ }^{\circ} \mathrm{C}$ for 5 days. Gram reactions were determined according to the non-staining method, as described by Buck (1982). Oxidase activity was evaluated via the oxidation of $1 \% p$-aminodimethylaniline oxalate. Catalase activity was determined by measuring bubble production after the application of a $3 \%(\mathrm{v} / \mathrm{v})$ hydrogen peroxide solution. Growth at a various temperatures $(4,15$, 25, 30, 37 and $42{ }^{\circ} \mathrm{C}$ ) was assessed on R2A agar, while growth at different $\mathrm{pHs}$ was assessed in R2A broth. Growth on nutrient agar, Luria-Bertani (LB) agar and trypticase soy agar (TSA) was also evaluated at $30{ }^{\circ} \mathrm{C}$. The API 20NE, API ID 32GN and API ZYM microtest systems were employed in these tests, according to the recommendations of the manufacturer (bioMérieux). Because strain DCY $12^{\mathrm{T}}$ was unable to assimilate any of the single growth substrates in the API 20NE and API ID 32GN tests, LB broth was added to the AUX medium $(0.1 \%, v / v)$ and then the microbial broth was inoculated; with LB broth as a growth factor, strain DCY $12^{\mathrm{T}}$ was then able to assimilate some substrates in these microtest systems. 
Isoprenoid quinones were extracted using chloroform/ methanol $(2: 1, \mathrm{v} / \mathrm{v})$, purified via TLC and subsequently analysed by HPLC, as described previously (Collins \& Jones, 1981; Shin et al., 1996). In order to perform a fatty acid methyl ester analysis, the strain was allowed to grow on TSA for $48 \mathrm{~h}$ at $30{ }^{\circ} \mathrm{C}$ and then two loops of the wellgrown cells were harvested. The fatty acid methyl esters were prepared, separated and identified with the Sherlock Microbial Identification System (MIS; MIDI) (Sasser, 1990).

To determine the $\mathrm{G}+\mathrm{C}$ content, genomic DNA was extracted and purified with the Genomic-tip 100/G system (Qiagen) and was then enzymically degraded into nucleosides. The nucleosides were analysed using HPLC, as described previously (Tamaoka \& Komagata, 1984; Mesbah et al., 1989).

The 16S rRNA gene was amplified from the chromosomal DNA using the universal bacterial primer set $9 \mathrm{~F}$ and $1512 \mathrm{R}$ (Weisburg et al., 1991) and the purified PCR product was sequenced by Genotec (Daejeon, Korea) (Kim et al., 2005). The complete sequence of the 16S rRNA gene was compiled with SeqMan software (DNASTAR). The $16 \mathrm{~S}$ rRNA gene sequences of related taxa were obtained from GenBank and edited using the BioEdit program (Hall, 1999). Multiple alignments were performed with the CLUSTAL_X program (Thompson et al., 1997). Evolutionary distances were calculated using the Kimura two-parameter model (Kimura, 1983) and a phylogenetic tree was constructed using the neighbour-joining method (Saitou \& Nei, 1987) in the MEGA2 program (Kumar et al., 2001). A bootstrap analysis, based on 1000 replicates, was also conducted in order to obtain confidence levels for the branches (Felsenstein, 1985). The closest relatives of strain DCY $12^{\mathrm{T}}$ and all of the type species representing all of the orders in the Betaproteobacteria and Gammaproteobacteria were included in the phylogenetic tree.

Strain DCY $12^{\mathrm{T}}$ was cultured on R2A agar at $30{ }^{\circ} \mathrm{C}$, yielding pale-yellow, circular colonies. The strain was found to be an aerobic, Gram-negative, non-motile bacterium consisting of short rod-shaped cells. Strain DCY $12^{\mathrm{T}}$ was also shown to be able to grow at $25-37{ }^{\circ} \mathrm{C}$, but it did not grow at 4 or $42{ }^{\circ} \mathrm{C}$. Physiological data for strain DCY $12^{\mathrm{T}}$ are summarized in the species description; Table 1 lists the differential characteristics with respect to related type strains.

The major cellular fatty acids in strain $\mathrm{DCY} 12^{\mathrm{T}}$ included $\mathrm{C}_{12: 0}(6.13 \%), \mathrm{C}_{14: 0}(7.12 \%), \mathrm{C}_{16: 0}(21.24 \%), \mathrm{C}_{12: 0} 2-$ $\mathrm{OH}(3.84 \%), \mathrm{C}_{16: 1} \omega 5 c(4.99 \%), \mathrm{C}_{18: 1}(25.90 \%), \mathrm{C}_{19: 0}$ cyclo $\omega 8 c(8.59 \%)$, summed feature $3\left(\mathrm{C}_{16: 1}\right.$ iso $\mathrm{I} / \mathrm{C}_{14: 0} 3-$ $\mathrm{OH} ; 13.25 \%)$ and summed feature $4\left(\mathrm{C}_{15: 0}\right.$ iso $2-\mathrm{OH} /$ $\left.\mathrm{C}_{16: 1} \omega 7 c ; 3.65 \%\right)$. Minor amounts of saturated fatty acids $\mathrm{C}_{15: 0}(1.36 \%), \mathrm{C}_{17: 0}(0.85 \%), \mathrm{C}_{18: 0}(0.62 \%), \mathrm{C}_{16: 0} 2-\mathrm{OH}$ $(1.31 \%), \mathrm{C}_{16: 0} 3-\mathrm{OH}(0.92 \%)$ and summed feature 2 $\left(\mathrm{C}_{15: 1}\right.$ iso $\left.\mathrm{H} / \mathrm{I} / \mathrm{C}_{13: 0} 3-\mathrm{OH} ; 0.25 \%\right)$ were also present.

The strain contained a ubiquinone with eight isoprene units $(\mathrm{Q}-8)$ as the predominant isoprenoid quinone. Q-8 is commonly found in species belonging to the Gammaproteobacteria.

The 16S rRNA gene sequence of DCY $12^{\mathrm{T}}$ was found to be a continuous stretch of $1491 \mathrm{nt}$, and the strain was found to belong to the class Gammaproteobacteria. The highest levels of sequence similarities for $\mathrm{DCY}_{12}{ }^{\mathrm{T}}$ occurred with Hydrocarboniphaga effusa AP103 ${ }^{\mathrm{T}}$ (89.2\%), Nevskia ramosa Soe1 $(88.8 \%)$ and Pseudomonas aeruginosa ATCC $10145^{\mathrm{T}}(83.2 \%)$. In the phylogenetic tree (Fig. 1), strain $\mathrm{DCY} 12^{\mathrm{T}}$ clearly belonged to the lineage containing the genera Hydrocarboniphaga and Nevskia, as evidenced by the high level of bootstrap support. On the basis of the $16 \mathrm{~S}$ rRNA gene sequencing results, the phylogenetic position of

Table 1. Phenotypic characteristics of strain $\mathrm{DCY} 12^{\top}$ and related taxa

Data for N. ramosa Soel and H. effusa $\mathrm{AP} 103^{\mathrm{T}}$ are from Stürmeyer et al. (1998) and Palleroni et al. (2004), respectively. None of the strains assimilated L-alanine. Strains $\mathrm{DCY} 12^{\mathrm{T}}$ and $\mathrm{AP} 103^{\mathrm{T}}$ grew on nutrient agar, LB agar and TSA, but did not grow at $42{ }^{\circ} \mathrm{C}$ and did not assimilate 4-hydroxybenzoate, 2-ketogluconate, malonate, maltose or melibiose. Strains DCY $12^{\mathrm{T}}$ and Soe1 did not assimilate citrate. + , Positive; -, negative; w, weakly positive; ND, no data available.

\begin{tabular}{|c|c|c|c|}
\hline Characteristic & DCY $12^{T}$ & $\begin{array}{l}\text { N. ramosa } \\
\text { Soe1 }\end{array}$ & $\begin{array}{c}\text { H. effusa } \\
\text { AP103 }^{\text {T }}\end{array}$ \\
\hline Motility & - & ND & + \\
\hline Cell length $(\mu \mathrm{m})$ & $0.3-0.5$ & $1.5-2.3$ & $1.5-2$ \\
\hline Cell width $(\mu \mathrm{m})$ & $0.2-0.4$ & $0.7-1.1$ & $0.75-0.85$ \\
\hline Catalase activity & + & $\mathrm{W}$ & ND \\
\hline $\begin{array}{l}\text { Optimum growth } \\
\text { temperature }\left({ }^{\circ} \mathrm{C}\right)\end{array}$ & 30 & ND & 28 \\
\hline Growth at $37^{\circ} \mathrm{C}$ & + & ND & - \\
\hline Lipase activity & - & ND & + \\
\hline \multicolumn{4}{|l|}{ Assimilation of: } \\
\hline DL-3-Hydroxybutyrate & + & $\mathrm{ND}$ & - \\
\hline Acetate & + & + & - \\
\hline Adipate & + & ND & - \\
\hline Caprate & - & ND & $\mathrm{W}$ \\
\hline Gluconate & + & ND & - \\
\hline DL-Lactate & - & + & + \\
\hline Malate & - & - & + \\
\hline Propionate & $\mathrm{w}$ & ND & + \\
\hline D-Glucose & + & + & - \\
\hline Mannose & - & ND & $\mathrm{w}$ \\
\hline Ribose & - & + & ND \\
\hline L-Rhamnose & - & ND & + \\
\hline Sucrose & - & + & w \\
\hline Mannitol & - & ND & + \\
\hline L-Histidine & + & ND & w \\
\hline L-Proline & W & ND & - \\
\hline L-Serine & $\mathrm{W}$ & $\mathrm{ND}$ & - \\
\hline $\begin{array}{l}\text { DNA G }+ \text { C content } \\
(\mathrm{mol} \%)\end{array}$ & 40.53 & 67.8 & 60 \\
\hline
\end{tabular}




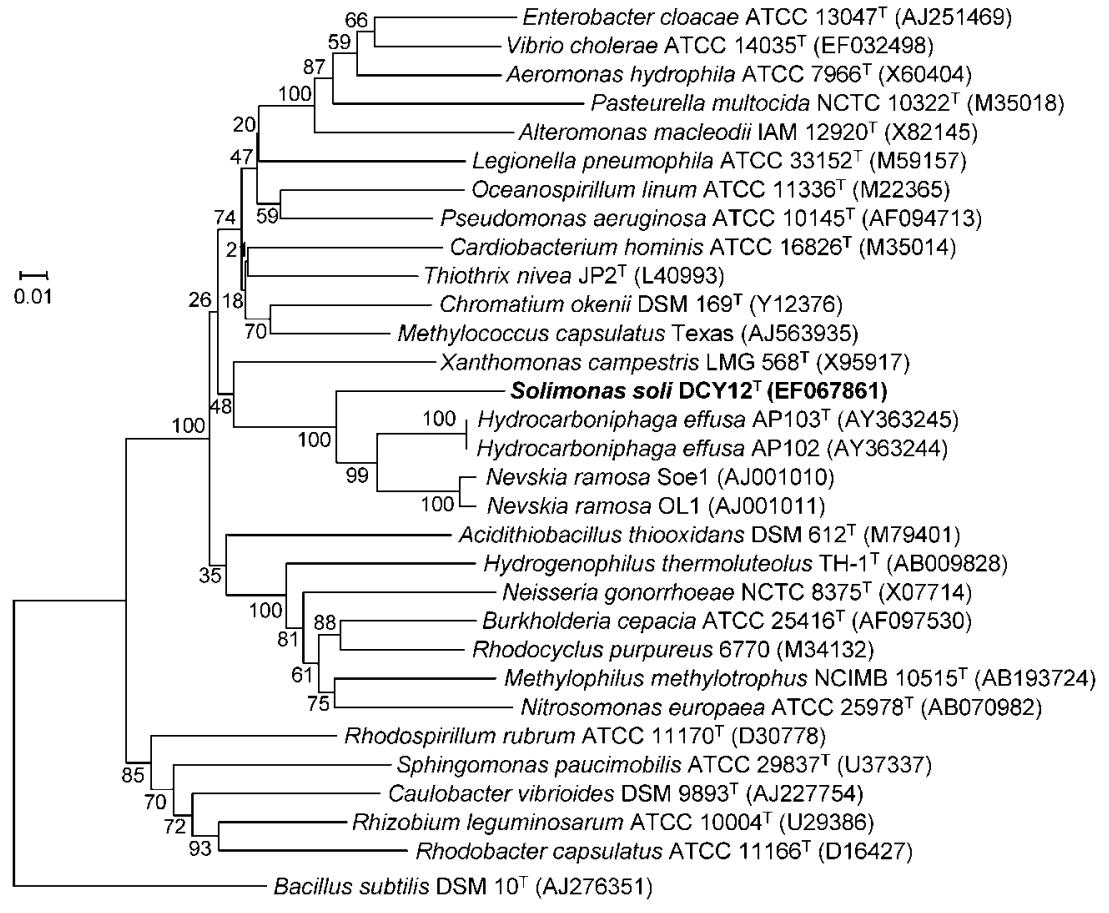

Fig. 1. Neighbour-joining phylogenetic tree, based on 16S rRNA gene sequences, showing the relationships between strain DCY $12^{\top}$ and related taxa. Bar, 0.01 substitutions per nucleotide position.
DCY $12^{\mathrm{T}}$ among members of the Gammaproteobacteria was unique and distinct.

In previous publications on the genera Nevskia and Hydrocarboniphaga, they were described as members of the Gammaproteobacteria, but no conclusive evidence was presented for this (Stürmeyer et al., 1998; Palleroni et al., 2004). In our study, $16 \mathrm{~S}$ rRNA gene sequences of the type species representing all of the orders in the Betaproteobacteria and Gammaproteobacteria were collected from GenBank and a phylogenetic tree was constructed. In Fig. 1, the Nevskia-Solimonas-Hydrocarboniphaga cluster is grouped with the Gammaproteobacteria, although its position is not supported by high levels of bootstrap support.

The G $+\mathrm{C}$ content of the genomic DNA of strain DCY $12^{\mathrm{T}}$ was $40.5 \mathrm{~mol} \%$, which is much lower than those of related taxa (N. ramosa, 67.8-69.0 mol\%; H. effusa, 60-61 mol\%).

On the basis of the phenotypic, chemotaxonomic and phylogenetic data, we conclude that strain $\mathrm{DCY} 12^{\mathrm{T}}$ represents a novel species and genus, within the Gammaproteobacteria, for which the name Solimonas soli gen. nov., sp. nov. is proposed.

\section{Description of Solimonas gen. nov.}

Solimonas (So'li.mo'nas. L. n. solum soil; L. fem. n. monas a unit, monad; N.L. fem. n. Solimonas a monad in soil).

Gram-negative, non-motile rods. Oxidase-negative and catalase-positive. The major ubiquinone is Q-8. The major cellular fatty acids are $\mathrm{C}_{16: 0}, \mathrm{C}_{18: 1}$ and summed feature 3 $\left(\mathrm{C}_{16: 1}\right.$ iso $\left.\mathrm{I} / \mathrm{C}_{14: 0} 3-\mathrm{OH}\right)$. The DNA $\mathrm{G}+\mathrm{C}$ content of the type strain of the type species is $40.5 \mathrm{~mol} \%$. The type, and only, species is Solimonas soli.

\section{Description of Solimonas soli sp. nov.}

Solimonas soli (so'li. L. neut. gen. n. soli of soil, the source of the type strain).

General characteristics are given above under the genus description. Cells grown on R2A agar at $30{ }^{\circ} \mathrm{C}$ for 5 days are $0.3-0.5 \times 0.2-0.4 \mu \mathrm{m}$, non-motile rods. Colonies grown on R2A agar plates for 5 days are pale yellow. Grows optimally at $30{ }^{\circ} \mathrm{C}$ and at $\mathrm{pH} 7.0$; growth occurs at 25$37{ }^{\circ} \mathrm{C}$ and $\mathrm{pH}$ 7.0-9.0 but not at temperatures above $42{ }^{\circ} \mathrm{C}$ or below $4{ }^{\circ} \mathrm{C}$ and not above $\mathrm{pH} 11$ or below $\mathrm{pH} 5$. Negative for indole production and acid production from glucose. Acid phosphatase, alkaline phosphatase, esterase, leucine arylamidase, naphthol-AS-BI-phosphohydrolase and urease are produced, but $N$-acetyl- $\beta$-glucosaminidase, arginine dihydrolase, $\alpha$-chymotrypsin, cystine arylamidase, $\alpha$-fucosidase, $\alpha$-galactosidase, $\beta$-galactosidase, $\alpha$-glucosidase, $\beta$-glucosidase, $\beta$-glucuronidase, lipase, $\alpha$-mannosidase, protease, trypsin and valine arylamidase are not produced. In the presence of LB broth as a growth factor, 3-hydroxybutyrate, acetate, adipate, gluconate, n-valerate, D-glucose and L-histidine are assimilated. Growth on propionate, L-arabinose, L-fucose, D-sorbitol, L-proline and L-serine, with R2A as a growth factor, is slow and very poor. No substrates are assimilated in the presence of yeast extract as a growth factor or in the absence of a growth factor. The following are not assimilated: 2ketogluconate, 3-hydroxybenzoate, 4-hydroxybenzoate, 5ketogluconate, caprate, citrate, itaconate, lactate, L-malate, 
malonate, phenylacetate, suberate, maltose, D-mannose, Dmelibiose, L-rhamnose, D-ribose, sucrose, myo-inositol, Dmannitol, L-alanine, $N$-acetyl-D-glucosamine, salicin and glycogen. Major cellular fatty acids include $\mathrm{C}_{16: 0}$ $(21.24 \%)$, summed feature $3\left(\mathrm{C}_{16: 1}\right.$ iso $\mathrm{I} / \mathrm{C}_{14: 0} 3-\mathrm{OH}$; $13.25 \%)$ and $\mathrm{C}_{18: 1}(25.90 \%)$. Nitrate is not reduced to nitrite or nitrogen gas.

The type strain, DCY $12^{\mathrm{T}}\left(=\right.$ KCTC $12834^{\mathrm{T}}=\mathrm{LMG} 24014^{\mathrm{T}}$ ), was isolated from soil from a ginseng field in South Korea.

\section{Acknowledgements}

This work was supported by a grant from the Plant Diversity Research Center of the 21st Century Frontier Research Program (PF06222-00) funded by the Ministry of Science and Technology of the Korean Government and by a BK21 research fellowship from the Ministry of Education and Human Resource Development, Korea.

\section{References}

Buck, J. D. (1982). Nonstaining (KOH) method for determination of Gram reactions of marine bacteria. Appl Environ Microbiol 44, 992-993.

Collins, M. D. \& Jones, D. (1981). Distribution of isoprenoid quinone structural types in bacteria and their taxonomic implications. Microbiol Rev 45, 316-354.

Felsenstein, J. (1985). Confidence limits on phylogenies: an approach using the bootstrap. Evolution 39, 783-791.

Hall, T. A. (1999). BioEdit: a user-friendly biological sequence alignment editor and analysis program for Windows 95/98/NT. Nucleic Acids Symp Ser 41, 95-98.

Kim, M. K., Im, W.-T., Ohta, H., Lee, M. \& Lee, S.-T. (2005). Sphingopyxis granuli sp. nov., a $\beta$-glucosidase-producing bacterium in the family Sphingomonadaceae in $\alpha-4$ subclass of the Proteobacteria. J Microbiol 43, 152-157.

Kimura, M. (1983). The Neutral Theory of Molecular Evolution. Cambridge: Cambridge University Press.

Kumar, S., Tamura, K., Jakobsen, I.-B. \& Nei, M. (2001). MEGA2: molecular evolutionary genetics analysis software. Bioinformatics 17, 1244-1245.

Mesbah, M., Premachandran, U. \& Whitman, W. B. (1989). Precise measurement of the $\mathrm{G}+\mathrm{C}$ content of deoxyribonucleic acid by highperformance liquid chromatography. Int J Syst Bacteriol 39, 159-167.

Palleroni, N. J., Port, A. M., Chang, H.-K. \& Zylstra, G. J. (2004). Hydrocarboniphaga effusa gen. nov., sp. nov., a novel member of the $\gamma$-Proteobacteria active in alkane and aromatic hydrocarbon degradation. Int J Syst Evol Microbiol 54, 1203-1207.

Saitou, N. \& Nei, M. (1987). The neighbor-joining method: a new method for reconstructing phylogenetic trees. Mol Biol Evol 4, 406-425.

Sasser, M. (1990). Identification of bacteria by gas chromatography of cellular fatty acids. MIDI Technical Note 101. Newark, DE: MIDI Inc.

Shin, Y. K., Lee, J.-S., Chun, C. O., Kim, H.-J. \& Park, Y.-H. (1996). Isoprenoid quinone profiles of the Leclercia adecarboxylata KCTC $1036^{\mathrm{T}}$. J Microbiol Biotechnol 6, 68-69.

Stürmeyer, H., Overmann, J., Babenzien, H.-D. \& Cypionka, H. (1998). Ecophysiological and phylogenetic studies of Nevskia ramosa in pure culture. Appl Environ Microbiol 64, 1890-1894.

Tamaoka, J. \& Komagata, K. (1984). Determination of DNA base composition by reversed-phase high-performance liquid chromatography. FEMS Microbiol Lett 25, 125-128.

Thompson, J. D., Gibson, T. J., Plewniak, F., Jeanmougin, F. \& Higgins, D. G. (1997). The CLUSTAL_X windows interface: flexible strategies for multiple sequence alignment aided by quality analysis tools. Nucleic Acids Res 25, 4876-4882.

Weisburg, W. G., Barns, S. M., Pelletier, D. A. \& Lane, D. J. (1991). 16 S ribosomal DNA amplification for phylogenetic study. J Bacteriol 173, 697-703. 